\title{
INDIAN MOUNDS OF SOUTHEASTERN IOWA
}

A radio talk (excerpted) by E. R. Harlan over W H O, Des Moines, Iowa, August 29, 1933.

\section{I.}

\section{How Came These Mounds?}

We speak of these as Indian mounds; but they are, ordinarily, merely burial places. They are imperfectly understood even by those who have tried scientifically to determine all about them.

It happens that in Iowa three-fourths of our streams flow almost parallel southeastward into the Mississippi River. From their upper reaches they first run in the soil, then onward to their mouths they are rocky in character. After the beds of the streams break down into the rocky country, they form low bluffs on one or the other side.

The ancient Sac and Fox Chi-ca-qua Sepo and Keosauqua Sepo (Skunk and Des Moines) so run, separated by an average of about thirty miles.

Southeast of Oskaloosa Cedar Creek rises in the prairie and as it flows, splits that ridge or prairie by its rather shallow system down into its region of hills and narrow, rocky, crooked bed. In Henry County it makes an abrupt turn to the north, and empties into Skunk River near the town of Rome.

Like all its sister streams, Cedar Creek is flanked by Indian mounds on all its higher hills. Just now, August, 1933, there is much more than usual interest in the mounds in that locality, since at least four are under "exploration."

Let me attempt my explanation of the occurrence of these "Indian mounds" on the crests of ridges overlooking all the valleys of southeastern Iowa, known to all the white people of each generation since settlement in 1837.

A mound opened in Cedar Township, Van Buren County, in the present month, has been explored at least once before.

I quote from the notes of United States Deputy Land Surveyor, Edwin F. Lucas, who laid out the section lines and 
set their corners, adjacent, on July 19, 1837 (96 years ago) :

Large wigwam surrounded on both sides [of the section line] with a beautiful sugar grove.

Also near:

Enter corn field claimed by Finess Killebrew, who is occupant and settler.

Ninety-six years ago a white man's cornfield was a few rods east of a large wickiup ${ }^{1}$ in a beautiful sugar grove, which I have seen, throughout more than sixty years, in use by my relatives for sugar making every February and March of each year; the grove, or its trees, replaced earlier ones that died off. The large wickiup which served an Indian family in 1837 and earlier, was built as early as 1832 , since Lucas saw it in 1837 in Finess Killebrew's claim. These relatives of mine, descendants of neighbors of Killebrew, still make sugar from these trees in 1933; these same Sac and Fox Indians annually returned to that "beautiful sugar grove" on Killebrew's claim for some years after. They made sugar there, and their descendants now living in Tama County, Iowa, are also making sugar along the Iowa River on their lands. I also know that the occupants of that large wickiup in 1837 were more than one family of Indians, else it would not have been a large wickiup. There were at least three families in it when it was new, which must have been at least five years earlier, or 1832, and each spring later up to 1837 . It was probably built to take the place of one that had rotted down, and that in turn had replaced an earlier one, and so on back perhaps for two hundred years. Each may have been but one of a village in that region. Time and hunger make no change, whatever races and methods do in the scheme of creation.

Now, that large wickiup in July, 1837, in the beautiful sugar grove on Killebrew's claim served a vital purpose other than for sugar making. The two or three families of Indians in the spring of 1837, and other years, had built that camp, or had repaired an earlier one in a previous fall, to receive the Indian families for fishing, trapping and hunting. It did

1 A Sac and Fox habitation was by themselves called a wickiup; by many white men it was called wigwam, as early eastern writers usually designated every Indian habitation. 
not cease serving for shelter after the trapping in the fall and winter of 1836, or of any year. It continued a home of these Indians for their sugar making in the early spring of 1837 . Each winter or spring it, or its predecessor, had so served for hundreds of seasons. Hence that one wickiup had been lived in by scores, yes, hundreds of individuals first and last.

And the sugar grove on Killebrew's claim on Cedar Creek was not the only one in that region. I remember more than twenty-five such beautiful sugar groves on the same or adjoining streams not twenty miles from that large wickiup. William Savage $^{2}$ trapped, hunted and made sugar on or adjacent to the Killebrew claim from 1855 to 1908 . From his diary I learn that in 1856 , and therefore earlier, there were taken in or near each of these twenty-five groves the pelts of deer, or raccoon, skunk, oppossum, muskrat and otter, all the skins of which were marketable, and most all the flesh of which was food, both fresh and dried, for later use elsewhere. Mr. Savage in and after 1855 shot or trapped on the grounds, not only many deer, but wild turkeys, pheasants (ruffed grouse), quails, geese, wild ducks of all kinds, brant, pigeons (passenger), every one edible and all afforded feathers for sale or family use in pillows and beds. Enough eggs of the first three species were found for use of the William Savage family in 1855, hence for use in the large wickiup and all the earlier wickiups for hundreds of years before 1837 .

This beautiful sugar grove was on both the low and high lands back from Cedar Creek for half a mile on its right and left. A perennial swamp or bog lay between the margin of the creek and the remoter base of the hills. This was kept damp by occasional overflow of the stream, or of the ravines, which separated the hills, in their drainage from their own headwaters. The run-off was retarded by rocks. Evaporation was delayed by dense shade of the beautiful sugar groves, whose undergrowth embraced every species of shrub or tree required for use for the comfort or safety of the Indian, and became so to his white successor-and that was everything of necessity and much for his acquired or fancied tastes. This

2 "9th [Feb, 9, 1858]. ... At night I watch my field, At 20 minutes before 8 o'clock I shot a young buck killing him on the spot." "William Savage Diary," AnNals of Iowa, Fol. XIX, p. 906. 
condition, repeated in twenty-five beautiful sugar camps separated by intervals of not more than four miles, on Cedar Creek for fifty miles of its lower reaches, and for an equal distance of the other streams confluent of the Mississippi River in Iowa, intimates potentially what was meant when a Sac or Fox spoke of the region in his word, ah yo i, "This is the place"-to worship, to trap, to hunt, to bathe, to be a creature among his brother creatures of his Manitou.

Now, the hilltops between those ravines are where the "Indian mounds" occur. They are to be accounted for by reflecting on the resemblance in all races, in all times, climes and countries of the feelings, philosophies and faiths regarding the dead. Starting with an understanding of these resemblances, we realize that in the disposition by the living of bodies of the dead (except in emergency, war and pestilence) all mankind are and have been prone to perform the rites or ceremonies of superstition or of sacred character, according to the viewpoint of the particular cult or inherited custom. No one, even the wildest wild Indian, neglected nor abused the sick nor the dead of his family, of his ereed or clan. He relieved the sick and took measures to protect his dead. In his scheme of things the Indian on Cedar Creek in and earlier than 1837 removed from the large wickiup any of which he was bereft-his spouse, his child, or even his friend-to that point or place to which, near the same camp, in previous winters or in earlier years, he had seen others of his dead interred. And precisely as at earlier times, he laid his dead in or on the ground, in nature's keeping. He protected the body as best he could from vandal beast or man. He covered it with leaves or snow or soil. From the bed of the ravine he worked a day or more carrying such stones as he could lift and placed them upon the grave, obscuring these with dirt that he carried in his basket or his blanket to help in hiding his sacred place, then left the friendly grass and falling leaves to do the rest. Loading his canoe with traps, his winter's catch of furs, his spring's run of maple sugar, and with the remaining members of his family, drifted toward his permanent summer home on or near the banks of the Mississippi. Life for him until the next fur season was with his family 
among their patches of pumpkins, corn and beans. This type of human life rotated with the seasons of all the years, and with fortunes of life for uncounted generations.

Some view is gained of summer life from the field notes of the original land survey fifty miles northeastward for Seventysix and Lake townships, Muscatine County, which were being surveyed at the same time as Killebrew's claim, but by Thomas Brown, between July 11 and September 13, 1837, as follows:

This township [Seventy-six, which is $76 \mathrm{~N}$, Range 3 West] has been the home of thousands of Indians, and not many years since. The whole range of bottom land immediately under the bluff has been covered with Indian diggings, as we call them, cornhills yet visible where they have cultivated many years ago. Indeed, I think it not surprising that either Whites or Indians should make this great cove a place of residence. The soil is in general of the first quality of prairie, the timber very convenient on the hillsides, and valleys which make through the bluff, and spring water of the best quality springs from the bluff in many places. .... There can be no doubt of the fertility of the soil. Many squatters prove this fact, having raised this season heavy crops of corn, potatoes, turnips, cabbage, etc. to great perfection. Many of them have now from 100 acres down to $1 \frac{1}{2}$ enclosed and cultivated.

\section{Of Lake Township Thomas Brown says :}

This township [adjoining Seventy-six on the south] abounds with an unusual quantity of rich soil, well adapted to the culture of corn, wheat, potatoes, flour, clover, herd grass, timothy, oats, barley, rye, etc., particularly the three latter species of grain. Pumpkins, melons and all kinds of vines, onions, ete. These articles can be rarsed in abundance, and the Red Cedar river is the channel by which a market will come to every man's door who may be a settler on this desirable spot. ....

\begin{tabular}{lccc}
\multicolumn{4}{c}{ Direc- } \\
Record & tion & Between & \\
Sec's & Chains \\
p 166 & E & $2-11$ & 31.25
\end{tabular}

$\begin{array}{lllr}\text { p } & 167 & \text { N } & 2-8 \\ & & & \\ \text { p } & 169 & \text { E } & 27-34 \\ \text { p } & 171 & \text { E } & 22-27 \\ \text { p } & 173 & \text { E } & 15-22 \\ \text { p } & 176 & \text { N } & 9-10\end{array}$

NE from this point is a cornfield 8 or 10 aeres claimed and occupied by Charley Phipps and Robert Holmes, who stay in an Indian wigwam, and claim $\mathrm{S} 1 / 2$ of Sec. 2.

60.00 Cluster of Indian wigwams, without inmates

78.21 Indian village evacuated

64.40 Indian trail NE

69.65 Indian trail SE

58.50 Indian trail NW

38.90 Indian trail NE

$\mathbf{5 8 . 7 5}$ Indian trail NE 


\section{p 177 E $\quad 3-10 \quad 20.00 \quad$ Indian trail NE \\ 57.59 From this point a cornfield and cabin bears south, claimed by George W. Clark, a settler.}

And so mounds grew for an unknown stretch of time. How many died at each camp where there was a beautiful grove no one knows. But it is known that Indian children and adults had every illness, except venereal disease, which white men know; that Asiatic cholera stopped not with white victims; that smallpox nor yellow fever knew no color.

\section{II.}

\section{How Mounds Should Be Regarded}

Now, I don't know what all legal rights in Indian mounds may be. Some good lawyer ought to make a brief of it. If he did, I apprehend he would find a few things which I $d o$ know. The owner of land on which a mound stands, according to Blackstone's doctrine, holds the title to the land, owns it, and all the ground contains, to the center of the earth and to the utmost height above it. If no arrangement is made for burial of a human body on a man's land, or such arrangement had not been made for such burial with the one from whom he bought the land, then that human body-yes, bad as it seems - that body absolutely is abandoned to, and it actually belongs, as "dust to dust," to the owner of the ground. Others have no right to go upon his land today withont his consent, and.if one does he is guilty of a trespass. Yet no one has the right to disturb a grave without consent of our State Board of Health, or an order of our District Court. We have sometimes, under the auspices of science, or out of mere curiosity, forgotten that the grave of an Indian is none the less a grave. Our health regulations require that it be shown of the dead on the United States standard certificate of death (Iowa Code, 1931, Ch. 110) of what " Color or race, as white, black, mulatto (or other negro descent), Indian, Chinese, Japanese, or other race." I don't know a rule of law or ethics that justifies one in disturbing any grave. If it be of a dead Indian, his grave was, and ought to remain, as much in our respect as ours in the respect of the Indian. He is entitled to be undisturbed 
until some consideration is raised that overcomes that right. The thing that usually is believed to overcome it is the interest of science, be that prehistoric lore, or the quest for Spanish or Mormon evidence, or such as identity of kinship. But even with the support of reason, one must obtain consent of the land owner, of the Board of Health, and of the District Court. But above all it is abhorrent to human feelings if one's kin or kind be disturbed after going to the long rest. What culture is exempt, or which may say of another that its feelings are immune?

Black Hawk died on the lower Des Moines River the third day of October, 1838. His people carried his body something more than a mile from his wickiup and buried him "in a sitting posture" in a low "mound" on the prairie. "On or about the first day of November, 1839," so the grand jury proceedings recite, "one Dr. James F. Turner removed the body." Afterward Black Hawk's widow and her friends went "to scatter tobacco [incense]" on the grave. Finding it desecrated, they went among their few white friends and, savage like, declared that for the outrage they were disposed to avenge themselves [on the settlement]. White men, to appease the Indians, took them to Governor Robert Lucas in Burlington, who promptly sent for Dr. Turner. The Doctor sent for Black Hawk's bones, that he had had articulated for alleged scientific purposes. Phrenology was then a new, "uplifting" force in the current of frontier life, calculated to carry the human race out into the fuller light of learning. Dr. Turner, a self-made pilot, proposed the exhibition of Black Hawk's skeleton in lectures and exhibitions with paid admissions. When Governor Lucas' emissary brought the skeleton to him, he called in Madam Black Hawk and suggested that she leave the bones of the great brave to the "cabinet" of the Historical Society. She inspected this and found it to be "a good dry (safe) place," too dry, in fact, for it was soon burned, and Black Hawk's bones with it.

There is another shocking instance of which I know. Fifty years ago a party from the Tama "reservation" of Sac and Foxes was trapping along an Iowa stream. Sickness and death came. An old lady among them died. Her body was 
put away in the earth just where her ancestors had lain for generations. Some men of her race who were then young and who helped to lay her away, returned in 1932 as old men to "decorate" that grave, not with flowers, but with incense. They saw the grave had been violated and found the body had been taken away. While trading in a nearby town they saw the "find" from that grave exhibited in a store window. My Tama friends were deeply hurt. I don't know whether the persons who "opened" that "mound" are yet aware of doing wrong.

There may be some question whether we ought to treat with much consideration the feelings of persons of another race, color or religion. But I hope the time will come when no disturbance of any grave will be made without the knowledge or consent of some public authority, which keeps permanent records, and makes definite plans and precise reports.

No one knows whether Indian cemeteries (mounds) are more free "of the dead from communicable diseases" than our own sacred acres. Our scientists set no period for vitality of such "germs" as "carry" diseases. The burial of Indian and white pioneers in Iowa, in and previous to 1837, were alike naked of preventive or destructive agents to disease germs. What stays the spade at one grave ought to spare it in the other, be it law, prejudice or sentiment.

In friendship these Indian Iowa voters inquired of me, a minor state official, in effect this: "What shall be done?" They were asked, "What can be done?" Neither query has been officially answered to this day. Yet the questioner in each retains in faith and consicence the assurance that if there is an Almighty Judge (which the cults of both teach us), be he God or Manitou or both, we will some day hear one truth, albeit beyond the grave. 
Copyright of Annals of Iowa is the property of State of Iowa, by \& through the State Historical Society of Iowa and its content may not be copied or emailed to multiple sites or posted to a listserv without the copyright holder's express written permission. However, users may print, download, or email articles for individual use. 